\title{
The Big Data Era: What are the Implications for the World of Accounting?
}

\author{
Rokhmat Taufiq Hidayat ${ }^{\text {a1 }}$, Akhmad Khabibi ${ }^{\text {b2 }}$ \\ ${ }^{1,2}$ Politeknik Keuangan Negara STAN, Indonesia \\ Email : rtaufiqhidayat@pknstan.ac.id, akhabibi@gmail.com \\ Corresponding Author
}

\section{ARTICLE INFO}

\section{Article history}

Received 2020-02-29

Revised 2020-08-28

Accepted 2020-09-14

Keywords

big data;

financial accounting; managerial accounting; auditing

\section{ABSTRACT}

In an era where information technology is developing so rapidly as it is now, contact with technology is inevitable. One that may often be heard is the use of big data. Although the development of big data has begun long before, its growth began rapidly since the Oxford Dictionary included the definition of big data in 2013. The use of big data is thought to have a big influence on the business world, and anything that influences the business world will certainly affect the world of accounting. Does the accountant anticipate these changes?

In this article, the author tries to explore what allusions might occur between the world of accounting and big data. Big data will increase the complexity of the accounting world by adding unstructured data in the accounting cycle. This presents a challenge for accountants but can also provide far greater added value if accountants are able to use it well.

The results of this study indicate that there are at least 3 areas in the field of accounting that are very likely to be exposed to the use of big data, namely in the process of financial accounting, managerial accounting, and auditing

\section{INTRODUCTION}

In today's world where the world is entering the Industrial Revolution 4.0, the term Big data is a term that is quite popular. The term Big data is not only popular in the world, but also in Indonesia. Along with the popularity of big data, it also affects many aspects of human life at this time, including in the business world. The world has recognized the value of data and products resulting from data analysis (Kalil, 2012).

There are many large companies in the world that have experienced the sweet results of big data analysis in their business decision making. In 2017, 53\% of multinational companies have adopted big data analysis, where the biggest users are telecommunication companies and financial companies (Columbus, 2017). For example at Starbucks. The largest coffee company in the world uses big data to analyze the potential success of opening each of its new outlets by analyzing location data, regional demographics, traffic, and consumer behavior data (O'Neill, 2016). By carrying out this in-depth analysis, it can be ascertained that the risk of failure rate from the opening of these new branches is very small.

Meanwhile, in Indonesia, there are not many examples of companies that carry out big data analysis. One of those who have done big data analysis is Go-Jek. One of the four unicorn companies in Indonesia has big data which contains personal data, travel history, food purchased, shopping list, massage schedule, car wash schedule. The data is then analyzed by artificial intelligent big data 
analysis to estimate customer desires when opening the Go-Jek application, so that the customer experience using the application becomes easier (Zuhra, 2017).

Then, what about the world of accounting? How big is the intersection between big data analysis and the world of accounting? What effect does big data have on the accounting profession? Furthermore, the author will discuss these problems in the discussion chapter.

\section{METHOD}

The method used in this research is literature study. The conceptual framework for the literature study that is implemented is an adaptation of the literature study method of Qadri (2019), Khan, Kunz, and Kleijnen (2003), as well as Tranfield, Denyer, and Smart (2003). In general, the steps taken are:

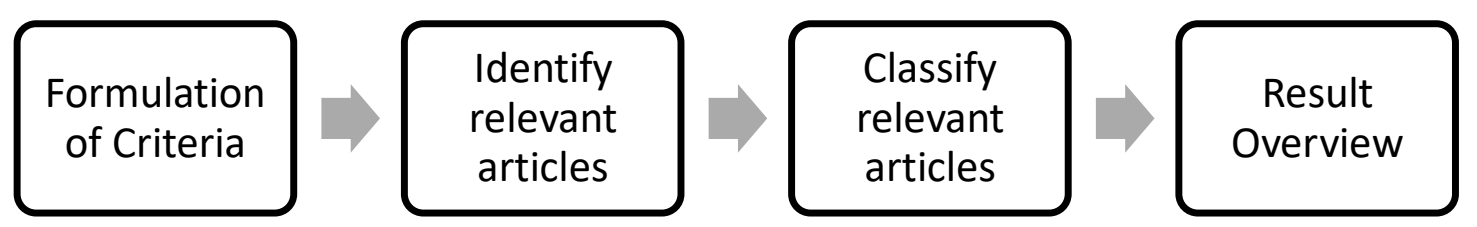

1

Figure 1.Stages of Literature Study (Qadri, 2019)

\section{RESULTS AND DISCUSSION}

Big data is an information asset that has the characteristics of Large Volume, Velocity and Variety which requires specific technology and analysis methods to transform it into value (De Mauro, et al., 2015). Furthermore, there are three characteristics of big data:

a. Volume: Big data involves a very large volume. The world is always adding to data at an exponential rate. In 2012, 2.5 exabytes of data were created each day. Take Walmart for example. It is estimated that Walmart generates 2.5 petabytes of data every hour from customer transaction data (McAfee \& Brynjolfsson, 2012). One petabyte is a thousand trillion bytes, or one million gigabytes. Imagine how much data can be generated from just one company.

b. Speed (Velocity): big data is also related to speed. In many applications, speed is even more important than data volume. For example in the Go-Jek application, when you open the Go-Jek application at 6 a.m., Go-Jek's artificial intelligent data analysis will immediately direct you to the nearest station, or when you open the application at 12 noon, the Go-Jek application Jek will direct you to buy the most popular foods in your area.

c. Type (Variety): If so far the data in the company has only been in the form of data query tables, then big data offers data consisting of various types of data, both structured and unstructured, for example messages, images on social media, finger sensors on smartphones, GPS signal, customer database, and more (McAfee \& Brynjolfsson, 2012).

Big data analysis involves various types of data, not just one type of query data. 


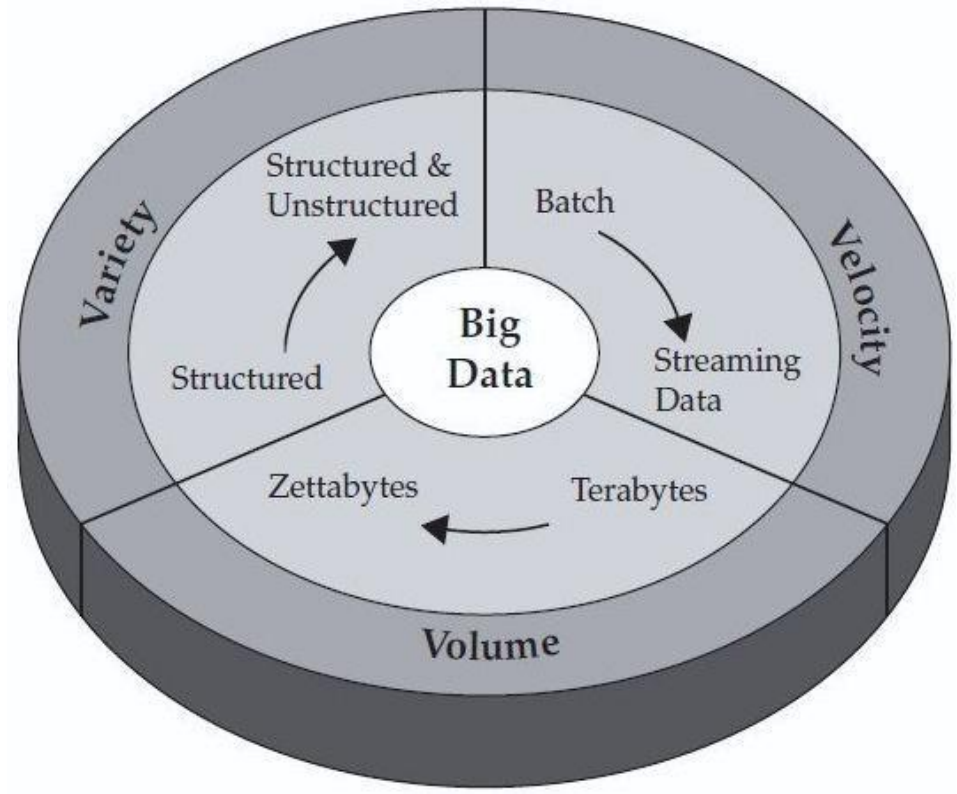

Figure 2 Characteristics of Big data

Source: (Jyothirmayee, et al., 2014)

Whatever the business sector, regardless of the size or size of the business, businesses can use big data analysis for the purposes of collecting, analyzing and interpreting data that is easier and more accessible at any time, and will certainly have a significant impact on their business activities (Marr, 2015 ). The following are the effects that big data can have on business actors.

1. Data will be viewed as an asset to every business

Every business produces data. For example, if a company has pages, social media accounts, customer transaction details, and so on. This means that every business needs a data collection strategy, how to analyze it, and how to protect it (Marr, 2015). So, if a businessman wants to improve his company's performance, that businessman has data that can be used to determine his company's strategy.

2. Making internal business operations more efficient

Big data analysis can help companies to operate their equipment more efficiently. An example of using big data at Starbucks to help make decisions in the future is an example of the application of big data in determining business policy. Another example can be obtained from google. At Google, big data analysis is used instantly to determine the Google Self-driving car route so that machine operating costs can be kept to a minimum (Jyothirmayee, et al., 2014).

\section{Increase Customer Experience}

Go-Jek can be used as the closest example of using big data for the benefit of customer experience. In Go-Jek, big data is used in addition to analyzing Go-Ride users' destinations and restaurant estimates that users will likely order at the Go-Food mentioned above, Go-Jek also uses big data to determine the fare for a trip. The fare of the trip can be immediately identified by the customer by processing the distance data obtained from the map and the rate per kilo meter.

This very fast process is very pleasant and profitable for customers because customers can make decisions to use Go-Jek or use other modes of transportation (Zuhra, 2017). 


\section{The Influence of Big Data on the World of Accounting}

Big data applications in the business world will of course have an impact on the world of accounting, including in helping management to make decisions, preparing financial reports, and auditing financial statements by auditors. Big data mainly affects the type of data that will be processed in the accounting process where the accounting process will not only process structured data, but will also add unstructured data.

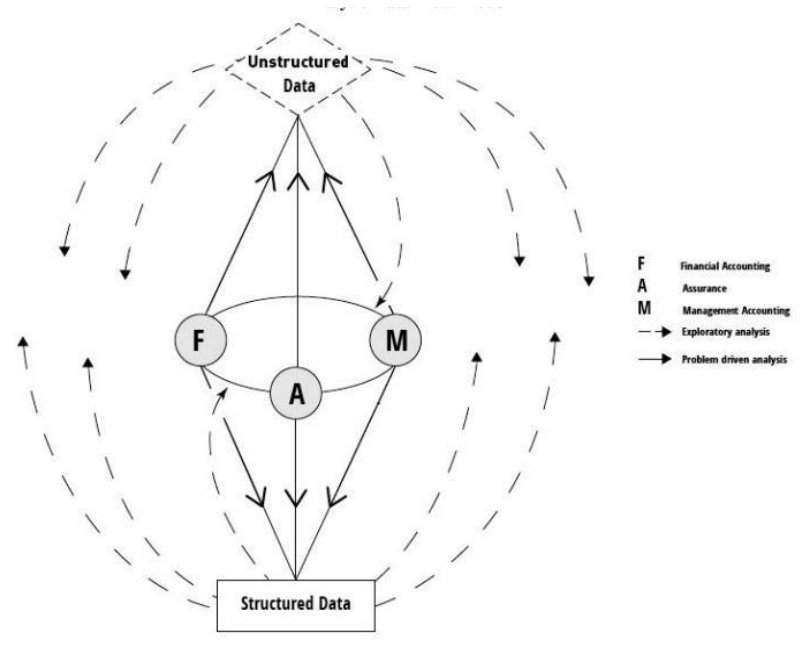

Figure 3 Analytic Data Flow Model

Source: (Richins, et al., 2017)

\section{Financial Accounting}

The first effect of big data on financial accounting is the use of increasingly varied data in accounting information systems (Rezaee \& Wang, 2019). If all this time the accounting information system has only obtained data from the input of accounting transaction data, then in the future the accounting information system will also use various kinds of data, for example GPS, text, video and audio recording data which are gradually juxtaposed with conventional accounting data. To anticipate this, of course an accountant must be able to improve his analytical skills to make peace with variations in data that are not only financial transaction data. With the use of increasingly richer data, financial accounting will produce more accurate financial information and can increase transparency, which is ultimately very useful for stakeholders to make decisions (Warren, et al., 2015).

The effect of big data on the next identified will occur in fair value accounting practices. Currently, there are companies whose line of business is to provide data provision by collecting and evaluating the required data from various sources, and the type of data that can be provided is the fair value of assets, liabilities. Moreover, these data providers are able to mitigate subjective assumptions in determining fair value (Rezaee \& Wang, 2019). The data provider agent works by continuously searching for relevant data on the web, storing in the cloud, compiling the data, and analyzing it so that it can increase the level of estimated fair value (Warren, et al., 2015). Thomson Reuters

Valuation Navigator is an example of an international company that provides financial data provision services in the form of providing, analyzing and evaluating fair value, and one of the countries that can get this service is Indonesia.

The widespread use of big data will also create opportunities for companies to generate intangible corporate assets that so far cannot be presented in the Financial Position Report, because the statement of financial position ignores several items of financial statements that cannot be determined 
objectively. There are several off-balance sheet assets that are likely to be raised because of this, including customers, human resources, commitment, product quality, service / goods providers, and company reputation (Warren, et al., 2015). The data required in the process of measuring the value of these assets can be collected, processed and analyzed with certain algorithms. Due to the development of increasingly advanced valuation methods, this will allow accounting to present items that have not been presented in the financial statements so far. Big data will play a very important role in this process. Not only that, big data can also revolutionize the accounting process which will affect the habits of accountants in conducting financial reporting.

\section{Managerial Accounting}

In addition to carrying out their role in formulating corporate strategy, accountants also contribute to strategy implementation and monitor the implementation of these strategies. By using big data, accountants can expand their monitoring techniques by leveraging relevant unstructured data to help them innovate in carrying out their duties to control the company.

Management accounting functions that have been proven to be helped by the use of big data include budget control. For example, Bestbuy can identify which items their potential customers do not like by using social media networking software, thus, Bestbuy can save costs by not making additional purchases of these unwelcome items (Richins, et al. ,2017). In addition to cost control, big data is also used to determine pricing strategies, for example Go-Jek. By utilizing data on hours, number of subscribers, location, traffic jams, and other data, Go-Jek can determine the optimal price for each available time, thus, Go-Jek can determine the price that benefits the company, and of course consumers, in real time and accurately (Zuhra, 2017).

The use of more complete data access, for example social media, allows accountants to carry out analyzes that have not been carried out in an easier and more efficient way. By utilizing customer voice analysis data from the call center and also email analysis, accountants can analyze whether a product has failed and then can quickly make recommendations to management which impact management's speed in making decisions. Another example is, by analyzing data on social media, accountants can find out whether a company's Corporate Social Responsibility program can be accepted by the public or not.

Big data can also play a role in the management control system by collecting, compiling, measuring, and evaluating employee and management behavior that correlates with specific company goals, which have previously been stated in the company's performance measurement system (Warren, et al., 2015). In simple terms, big data can collect employee and management behavior that can improve company performance and this data can be displayed on a dashboard which is always monitored by authorized managers. For example, a company could track time spent on telephone services, which could then be used to analyze marketing employee productivity. In addition, by analyzing the vocal tone of the telephone recipient, and by combining it with an unlimited number of other data, accountants can analyze what factors affect employee morale (Warren, et al., 2015).

The use of big big data can be very beneficial for managers to make the right decisions at all times in order to ensure that the company's targets can be achieved, not only in the short term, but also in the long term.

\section{Audit}

Currently, auditors face big challenges in the form of massive data piles in the form of structured data (for example ledgers or transaction data) and unstructured data (for example e-mail, voice messages, videos, WiFi access registration, etc.) which of course are still will be combined with nontraditional data from external parties such as news, social media, and external publications (Rezaee \& Wang, 2019). The implication of the use of big data by management is that an auditor must be able to perform big data analysis to balance management who already has and actively utilizes big data. 
Not only does it provide challenges, other impacts from the use of big data analysis by auditors can also provide benefits. The use of big data in auditing can provide strong predictive power for auditors, which is a very profitable capital for an auditor. In addition, Big data can also provide very diverse data and is very useful to assist auditors in identifying potential fraud (Alles \& Gray, 2016).

\section{CONCLUSION}

In this article, the author has explained that the accounting world must start using unstructured data in its processing. Areas of exposure to the use of this new form of data are in the process of financial accounting, managerial accounting, and the world of auditing. Utilization of this data will certainly enrich accounting source data so that it is expected to be able to improve the quality of information that will be produced by accounting so that the decision making that will be taken by stakeholders is more precise.

The impact of big data applications will bring its own complexities to accounting practices. In financial accounting, the accounting information system must provide a place not only for transaction data originating from general journals, but also must prepare a place for unstructured data, for example GPS, text, video, and audio recording data. It is not easy, but it will promise more accurate and transparent financial information, so that the quality of financial reports will be higher. In the world of managerial accounting, big data seems to offer more benefits with its use in management control systems and cost control. The use of big data allows management to monitor important company data in real time with the management control dashboard. In the world of auditing, auditors must be able to beat the big data challenge, especially if the company uses big data in its business processes.

Big data results in changes to existing business processes, so that Kuntan must evolve and start to take advantage of big data analysis in carrying out the mandate of his profession. The world is constantly changing, and accountants must choose to change or be defeated by the changes.

\section{REFERENCE}

Alles, M. \& Gray, G., 2016. Incorporating big data in audits: Identifying inhibitors and a research agenda to address those inhibitors. International Journal of Accounting, pp. 44-59.

Columbus, L., 2017. Forbes. [Online] Available at: https://www.forbes.com/sites/louiscolumbus/2017/12/24/53-of-companies-are-adopting-big-dataanalytics/\#443a9c3139a1

De Mauro, A., Greco, M. \& Grimaldi, M., 2015. What is big data? A consensual definition and a review of key research topics. s.l., AIP Publishing, p. 97.

Jyothirmayee, A. V. N. S., Reddy, G. S. \& Akbar, K., 2014. Understanding Big data \& DV2 law. International Journal of Emerging Technology and Advanced Engineering, pp. 688-695.

Kalil, T., 2012. The White House President Barrack Obama. [Online] Available at: https://obamawhitehouse.archives.gov/blog/2012/03/29/big-data-big-deal

Marr, B., 2015. Forbes. [Online] Available at: https://www.forbes.com/sites/bernardmarr/2015/09/08/4ways-big-data-will-change-every-business/\#6a5778862729

McAfee, A. \& Brynjolfsson, E., 2012. Harvard Bussiness Review. [Online] Available at: https://hbr.org/2012/10/big-data-the-management-revolution 
O'Neill, E., 2016. CA Today. [Online] Available at: https://www.icas.com/ca-today-news/10-companiesusing-big-data

Rezaee, Z. \& Wang, J., 2019. A Plus. [Online] Available at: https://aplusmag.goodbarber.com/topics/c/0/i/17867251/big-data-big-impact-accounting

Richins, G., Stapleton, A., Stratopoulos, T. C. \& Wong, C., 2017. Big data Analytics: Opportunity or Threat for the Accounting Profession?. JOURNAL OF INFORMATION SYSTEMS, p. 63-79.

Warren, J. D., Moffit, K. C. \& Byrnes, P., 2015. How Big data Will Change Accounting. Accounting Horizons, pp. 397-407.

Zuhra, W. U. N., 2017. Tirto-id. [Online] Available at: https://tirto.id/bagaimana-data-penggunamemberi-untung-bagi-go-jek-cukG 